\title{
PERSEPSI SISWA TENTANG MANIFESTASI TUGAS-TUGAS PERKEMBANGAN REMAJA SISWA KELAS XI SMA.NEGERI 11 SAMARINDA
}

\author{
MERLY HANDAYANI \\ Universita Mulawarman \\ Email : $\underline{\text { Merlyhandayanipaleme@gmail.com }}$
}

\begin{abstract}
Abstrak
Tugas-tugas perkembangan remaja merupakan tugas yang muncul pada saat atau sekitar satu periode tertentu dari kehidupan individu, namun kenyataanya tidak semua siswa paham dengan wujud tugas-tugas perkembangan remaja yang dialami. Rumusan masalah dalam penelitian ini adalah " Bagaimana persepsi siswa tentang manifestasi tugas-tugas perkembangan remaja siswa kelas XI Di SMA.Negeri 11 Samarinda Tahun Pembelajaran 2014/2015". Sedangkan tujuan dalam penelitian ini adalah untuk mengetahui persepsi siswa tentang manifestasi tugas-tugas perkembangan remaja kelas XI Di SMA.Negeri 11 Samarinda Tahun Pembelajaran. Jenis penelitian ini adalah kualitatif deskriptif di mana fokus penelitiannya yaitu persepsi siswa tentang manifestasi tugas-tugas perkembangan remaja. Penelitian ini dilaksankan di SMA. Negeri 11 Samarinda dengan populasi penelitian adalah siswa kelas XI SMA Negeri 11 Samarinda Tahun pembelajaran 2014/2015 yang berjumlah 144 Siswa sehingga penulis mengambil sampel 75\% dari jumlah populasi, yaitu 108 siswa. Metode pengumpulan data yang digunakan adalah angket sebagai metode pokok dan doumentasi sebagai metode pelengkap.sedangkan teknik analisis data yaitu rumus interval dan persentase Dari hasil pengelolahan data pada 108 siswa kelas XI SMA Negeri 11 Samarinda, responden sebanyak 108, maka sebanyak 47 siswa responden berpersepsi baik, dengan jumlah persentase 43,51\%, 19 siswa berpersepsi sangat baik, dengan jumlah presentase 17,59\%, 36 siswa berpersepsi cukup baik, namun demikian masih ada siswa yang berpersepsi tidak baik yang terlihat dari data diatas sekitar 6 siswa atau 5,55\%. Hinggah hasil penelitian menunjukan bahwa persepsi siswa tentang manifestasi tugas-tugas perkembangan remaja, BAIK, karena terlihat sekitar dari 108 siswa sebanyak 47 siswa dengan persentase 43,51\% berpersepsi BAIK tentang manifestasi tugas-tugas perkembangan remaja DI SMA Negeri XI Samarinda.
\end{abstract}

Kata Kunci: Persepsi, Manifestasi, Perkemabangan Remaja

\begin{abstract}
Youth development tasks are tasks that arise at or around a certain period of individual life, but in reality not all students are familiar with developing youth development tasks. The formulation of the problem in this study is "What are the
\end{abstract}


students' perceptions about the manifestation of the youth development tasks of class XI in SMA. Negeri 11 Samarinda 2014/2015 Academic Year". While the purpose of this study was to study students' perceptions about the manifestation of the task of developing class XI youth in SMA Negeri Negeri 11 Samarinda in the Year of Learning. This type of research is descriptive qualitative where the focus of research is students' perceptions about the manifestation of youth development tasks. This research was carried out in high school. Negeri 11 Samarinda with research participation was a class XI student at SMA Negeri 11 Samarinda in the 2014/2015 academic year that encouraged 144 students to become writers taking a sample of $75 \%$ of the total population, namely 108 students. The data collection method used was a questionnaire as the main method and documentation as a complementary method. While the data analysis technique was the interval and percentage formula. From the results of data management in 108 class XI students of SMA Negeri 11 Samarinda, 108 respondents, then 47 students of respondents had a good perception, with a percentage of 43.51\%, 19 students had a very good perception, with a percentage of 17.59\%, 36 students have a pretty good perception, however there are still students who have a bad perception that can be seen from the data above about 6 students or 5.55\%. The results of the study showed that students' perceptions about the manifestation of youth development tasks, GOOD, because seen from 108 students as many as 47 students with a percentage of $43.51 \%$ had a GOOD perception about the manifestation of youth development tasks in SMA Negeri XI Samarinda.

Keywords: Perception, Manifestation, Youth Branching

\section{PENDAHULUAN}

Tugas tugas perkembangan merupakan suatu proses yang menggambarkan perilaku kehidupan sosio-psikologis manusia pada posisi yang harmonis didalam lingkungan masyarakat yang lebih luas dan kompleks. Proses tersebut merupakan tugas tugas perkembangan fisik dan psikis yang harus dipelajari, dijalani, dan dikuasai oleh setiap individu. Pada jenjang kehidupan usia sekolah menengah ( remaja ), seseorang telah berada pada posisi yang cukup kompleks karena ia telah banyak menyelesaikan tugas tugas perkembangannya, seperti proses mempelajari nilai dan norma pergaulan dengan teman sebaya, menyesuaikan diri dengan ketentuan yang berlaku.

Secara sadar, pada akhir masa anak anak seseorang individu akan berupaya untuk bersikap dan berperilaku lebih dewasa dan intelek. Hal ini 
merupakan "tugas" yang cukup berat bagi para remaja untuk lebih menuntaskan tugas tugas perkembangannya, sehubungan dengan semakin luas dan kompleksnya kondisi kehidupan yang harus dihadapi dan dijalani oleh remaja. Mereka tidak ingin dijuluki sebagai anak-anak, melainkan ingin dihargai dan diakui sebagai orang yang sudah dewasa. Mereka menjalani tugas mempersiapkan diri untuk dapat hidup lebih dewasa, dalam arti mampu menghadapi dan memecahkan masalah, bertindak etis dan normatif serta bertanggung jawab moral. Oleh karena itu, tugas perkembangan pada masa remaja ini dipusatkan pada upaya untuk menanggulangi sikap dan pola kekanak-kanakan.

Tugas tugas perkembangan tersebut oleh Havighurs dikaitkan dengan fungsi belajar karena pada hakikatnya perkembangan kehidupan manusia dipandang sebagai upaya mempelajari nilai dan norma kehidupan sosial budaya agar mampu melakukan penyesuaian diri dalam kehidupan nyata di masyarakatnya. Oleh karena itu, jenis tugas perkembangan remaja itu mencakup segala persiapan diri untuk memasuki jenjang waktu, yang intinya bertolak dari tugas perkembangan fisik dan tugas perkembangan sosio- psikologis.

Tugas tugas perkembangan tersebut pada dasarnya tidak dapat dipisahkan karena remaja adalah pribadi yang utuh secara individual dan sosial. Namun demikian, banyak hal yang harus diselesaikan selama masa perkembangan remaja yang singkat ini. Pada tugas perkembangan fisik, upaya untuk mengatasi permasalahan pertumbuhan yang "serba tak harmonis" amatlah berat bagi para remaja. Hal itu dapat bertambah sulit bagi remaja yang sejak masa anak-anak telah memiliki konsep yang mengagungkan penampilan diri pada waktu dewasa nanti, oleh karena itu tidak sedikit remaja bertingkah kurang tepat (kurang sesuai).

Secara umum, kenakalan remaja ini cenderung pada kategori tindakan kriminal. Hal ini terbukti dengan adanya tindakan remaja ( siswa ) antara lain pencurian, seks bebas, pemakaian obat terlarang, tindakan aborsi, pembunuhan dan tindakan krimanal lainnya marak terjadi dikalangan remaja saat ini. Masalah ini bila segera tidak diatasi akan semakin mengancam kehidupan generasi bangsa 
khususnya dan tata kehidupn sosial masyarakat pada umumnya. Hal ini diakibatkan karena banyaknya remaja yang belum terlalu paham dengan tugas perkembangan mereka, apa yang harus mereka lakukan, dan tidak sebaliknya ada yang paham tetapi menyalahgunakan contohnya pada tugas perkembangan remaja yang harus menyesuaikan diri dengan perubahan fisiologis-psikologis karena pada pada sisi ini remaja harus memenuhi kebutuhan dorongan biologis ( seksual ), namun bila dipenuhi hal itu pasti akan melanggar norma-norma sosial. Oleh karena itu remaja menghadapi dilema dengan demiian remaja dituntut untuk dapat menyesuaikan diri dengan baik.

Secara khusus di sekolah yang menjadi tempat penelitian penulis tingkat Sekolah Menengah Atas (SMA) masih ada sebagian remaja yang belum mencapai tugas perkembangan remaja seusia mereka contohnya pada tugas perkembangan yang mencapai peran sosial sebagai laki-laki atau wanita. Masih ada saja laki-laki yang bertingkah seperti wanita, dan sebaliknya wanita bertingkah seperti laki-laki hingga menyerupai kaum laki-laki seutuhnya. Dan masih ada saja remaja yang tidak menerima keadaan tubuhnya (fisiknya ). Oleh karena itu, berdasarkan uraian latar belakang di atas maka dapat dirumuskan masalah dalam penelitian yaitu “ Bagaimana Persepsi Siswa Tentang Manifestasi Tugas Tugas Perkembangan remaja, Siswa Kelas XI Di SMA. Negeri 11 Samarinda Tahun Ajaran 2014/2015 ?"

\section{TINJAUAN PUSTAKA}

\section{Persepsi}

Kartini Kartono, (1990:94) "pengertian persepsi adalah mengalami seseuatu dalam pengertian melihat sesuatu, mendengar sesuatu, mengadakan seseuatu pemisahan antara diri sendiri (subjek) dengan objek yang dihayati”. Jadi persepsi dimulai dari terlihat objek yang dipandangi. Sedangkan Bimo Walgito (2002:45) menyatakan bahwa "persepsi adalah merupakan satu prosese diterimanya stimulus oleh individu melalui alat penerimanya yaitu indera, namun proses tersebut tidak berhenti disitu saja, pada umumnya stimulus tersebut 
diteruskan oleh syaraf ke otak sebagai pusat susunn syaraf, dan proses selanjutnya merupakan proses persepsi." Jadi persepsi dapat terjadi karena terjadinya proses stimulus oleh individu pada indera lalu diteruskan keotak, sehingga tejadinya proses persepsi.

Irwanto dalam bukunya psikologi umum (1994:43) mengatakan bahwa “persepsi adalah suatu proses yang didahuli oleh penginderaan". Penginderaan ini adalah suatu proses yang dimana stimulus diterima oleh individu melalui alat indera yang sempurna serta informasi yang telah didapat sebelumnya terdapat obyek/fakta yang diterima oleh dirinya. Jadi proses terjadinya persepsi dimulai oleh alat indera yang berupa stimulus terhadap obyek yang ada sehingga stimulus tersebut dapat menjadi suatu fakta yang dapat diterima oleh dirinya.

Dari pengertian tersebut dapat disimpulkan bahwa persepsi adalah suat proses terjadinya stimulus dimana setiap stimulus yang akan datang pada individu akan melewati indera dan indera tersebut yang akan menyampaikan pada sistem syaraf otak yang selanjutnya merupakan persepsi

\section{Jenis-jenis Persepsi}

Irwanto (1994:71) mengemukakan bahwa "jika dilihat dari segi individu setelah melakukan persepsi interaksi dengan objek yang ada dipersepsinya maka hasil persepsi itu dapat dibagi menjadi dua". yaitu:

a. Persepsi positif adalah persepsi yang menggambarkan segala pengetahuan serta tanggapan yang selaras dengan objek yang dipersepsikannya.

b. Persepsi negative dalah persepsi yang menggambarkan segala pengetahuan serta tanggapan yang tidak selaras dengan objek yang diperhatikannya.

Jadi, dari pendapat diatas penulis dapat meyimpulkan bahwa jenis persepsi dibagi menjadi dua bagian yaitu, persepsi positif dan persepsi negative. Maka untuk menentukan jenis persepsi dalam penilitian ini penulis menggolongkan empat golongan, yaitu : 
a. Persepsi sangat baik, yaitu pandangan atau pendapat yang sangat baik terhadapap suatu objek

b. Persepsi baik, yaitu pandangan atau pendapat yang baik terhadap suatu objek.

c. Persepsi cukup, yaitu pandangan atau pendapat yang cukup terhadap suatu objek.

d. Persepsi tidak baik, yaitu pendangan atau pendapat yang kurang terhadap suatu objek.

\section{Proses Terjadinya Persepsi}

Dalam proses persepsi perlu adanya perhatian sebagai langkahpersiapan dalam persepsi itu. Hal tersebut karena menunjukan bahwa individu tidak hanya dikenai oleh satu stimulus saja, tetapi individu dikenai berbagai macam stimulus yang ditimbulkan oleh keadaan sekitarnya. Namun demikian tidak semua stimulus mendapatkan respon individu untuk dipersepsi. Stimulus mana yang akan dipersepsi akan mendapatkan respons dari individu tergantung pada perhatian individu yang bersangkutan.

Proses terjadinya pesepsi dapat dijelaskan sebagai berikut : individu menerima macam-macam stimulus yang datang dari lingkungan, tetapi tidak semua stimulus akan diperhatikan atau akan direspons. Individu mengadakan seleksi terhadapap stimulus yang mengenainya, dan disini yang berperannya perhatian. Sebagai akibat dari stimulus yang dipilinya diterima oleh individu, individu menyadari dan memberikan respons sebagai reaksi terhadap stimulus tersebut. Tidak semua stimulus akan direspon oleh organism atau individu. Respons diberikan oleh individu trhadap stimulus yang ada persesuaian atau yang menarik perhatian individu.

Dengan demikian bahwa yang dipersepsi oleh individu selain tergantung pada stimulusnya juga tergantung pada keadaan individu yang bersangkutan. Stimulus yang mendapatkan pemilihan individu 
tergantung pada macam-macam faktor, salah satu faktor adalah perhatian individu, yang merupakan aspek psikologis individu dalam mengadakan persepsi.

\section{Pembahasan Tentang Tugas-tugas Perkembangan Remaja Pengertian Perkembangan remaja}

Perkembangan berarti perubahan secara kualitatif, ini berarti bahwa perkembangan bukan sekedar penambahan tiap senti pada tinggi badan seseorang atau kemampuan seseorang, melainkan suatu proses integrasi dari banyak struktur dan fungsi yang kompleks.

Dalam Kamus Bahasa Indonesia Kontemporer, perkembangan adalah perihal berkembang, mekar, terbuka membentang, mejandi besar, luas, banyak, dan sebagainya. Kata berkemabang tidak saja meliputi aspek yang bersifat abstrak dalam hal kualitas, seperti pikiran dan pengetahuan, namun juga bersifat konkret yang menunjukkan perkembnagan positif. Perkemabngan menurut istilah adalah development, yang merupakan rangkaian yang bersifat progresif dan terartur dari fungsi jesmaniah dan ruhaniah sebagai akibat pengaruh kerja sama antara kematangan (maturation) dan pelajaran (learning).

Seorang ahli interaksionimisme ( Piaget : 1947 ) yang dikutip dalam buku Baharuddin (2009: 69) berpendapat bahwa perkembangan mementingkan perkembangan intelektual dan perkembangan moral yang saling berhubungan. Moral dipandang dengan intelektual anak, perkembangan berjalan melalui stadium dan membawa anak dari tingkatan sturktur yang lebih tinggi.

Perkembangan (development) adalah suatu proses tahapan pertumbuhan ke arah yang lebih maju. Perkembangan melibatkan proses perubahan kualitatif yang mengacu pada mutu fungsi-fungsi organ jesmaniah. Dengan kata lain, penekanan arti perkembangan itu terletak pada penyempurnaan fungsi psikologis yang disandang oleh organ-organ fisik.

Munurut Mussen dkk. (1984) yang dikutip dalam buku Baharuddin ( 2009 : 69 ) " development in its most general psychological sense refers to certain canges that occurs in human beings (or animals) between conception and death" 
(perkembangan merupakan suatu perubahan yang terjadi pada manusia atau hewan diantara konsepsi sampai meninggal dunia.

Dari beberapa pengertian di atas dapat disimpulkan bahwa perkembangan merupakan perubahan yang menuju kesempurnaan berkaitan dengan psikis yang bersifat kualitatif yang menyatu pada mutu fungsi organ-organ jasmaniah atau penyempurnaan fungsi psikologis yang disandang oleg organ-organ fisik.

Istliah asing yang sering digunakan untuk menunjukan masa remaja menurut Singgih D.Gunarsa (2004: 13) adalah antara lain : (a) puberteit, puberty dan (b) adolescentia. Istilah puberty (bahasa inggris) berasal dari istilah latin, pubertas yang berarti kelaki-lakian, kedewasaan yang dilandasi oleh sifat dan tanda-tanda kelaki-lakian. Pubesence dari kata, pubis (pubic hair) yang berarti rambut (bulu) pada daerah kemaluan (genital), maka pubesence berarti perubahan yang dibarengi dengan tumbuhnya rambut pada daerah kemaluan.

Adolescentia berasal dari istilah latin yang berarti masa muda yang terjadi antara 17-30 tahun, Yulia dan Singgih D.gunarsa akhirnya menyimpulkan bahwa proses perkembangan psikis remaja dimulai antara 12-22 tahun. Jadi, remaja (adolescence) adalah masa transisi /peralihan dari masa kanak-kanak menuju masa dewasa yang ditandai dengan adanya perubahan aspek fisik, psikis, dan psikososial. Penggolongan remaja menurut Thornburg (1982) dikutip dalam buku Agoes Dariyo ( 2004:14) bahwa remaja terdiri dari 3 tahap, yaitu (a) remaja awal ( usia 13-14 tahun), (b) remaja tengah ( usia 15-17 tahun) dan (c) remaja akhir ( usia 18-21 tahun). Masa remaja awal, umumnya individu telah memasuki pendidikan dibangku sekolah menengah tingkat pertama (SLTP), sedangkan masa remaja tengah individu sudah duduk di sekolah menengah atas (SMU). Kemudian mereka tergolong remaja akhir, umunya sudah memasuki dunia perguruan tinggi atau lulus SMU dan mungkin sudah bekerja. 


\section{METODE PENELITIAN}

\section{Lokasi Penelitian}

Adapun lokasi pelaksanaan penelitian yaitudi SMA Negeri 11 Samarinda, Jln.H.Marhusen, Pelita IV Sambutan- Samarinda Ilir.

\section{Data dan Sumber Data}

Dalam suatu kegiatan penelitian, perlu ditetapkan populasi yang akan diteliti, hal itu dimaksudkan untuk dapat mengetahui besar kecilnya populasi yang dapat mempengaruhi hasil penelitian. Menurut Moleong (2004: 224) “ sampel pada penelitian kualitatif ini adalah dengan menggunakan purposive sampling " . Di dalam peneltian kualitatif ini tidak ada sampel acak-acak, tetapi sampel bertujuan.

Berdasarkan pendapat tersebut, maka penulis akan mengambil sampel berdasarkan tujuan tertentu yaitu untuk mengetahui persepsi siswa tentang manifestasi tugas-tugas perkembangan remaja Di SMA Negeri 11 Samarinda. Dengan demikian sumber datanya berjumlah orang siswa dari empat kelas.

\section{Teknik Pengumpulan Data}

Dalam penelitian suatu masalah selalu menggunakan teknik tertentu untuk memperoleh data yang sesuai dengan obyek penelitian, sehubungan dengan ini maka peneliti memakai teknik sebagai berikut :

\section{Angket}

Menurut pendapat Winkel \& Sri Hastuti ( 2007 : 270 ) menyatakan bahwa alat ini memuat sejumlah item atau pertanyaan yang harus dijawab oleh siswa secara tertulis.

Menurut Slameto ( 2001 : 128 ) “ kuisioner adalah merupakan suatu daftar pertanyaan-pertanyaan tertulis yang harus dijawab oleh siswa yang menjadi sasaran dari kuisioner tersebut maupun orang lain “

Sedangkan menurut Sugiyono ( $2006: 199$ ) “ angket merupakan teknik pengumpulan data yang dilakukan dengan cara memberikan 
seperangkat pertanyaan atau pertanyaan tertulis kepada responden untuk dijawab.

Jadi angket adalah alat pengumpulan data yang dilaksanakan dengan cara pemberian suatu pertanyaan secara terulis kepada responden, kemudian hasilnya digunakan untuk data tentang persepsi siswa tentang manifestasi tugas-tugas perkembangan remaja.

Dalam penyusunan angket ini yakni angket berstruktur yaitu angket yang menyediakan kemungkinan jawaban. Bentuk jawaban angket berstruktur adalah bentuk tertutup, yakni angket yang ada pada setiap itemnya sudah tersedianya alternative jawaban.

\section{a. Penyusunan item pernyataan}

Penyusunan item pernyataan ini berpedoman pada kisi-kisi pedoman penyusunan angket yang telah ditentukan, sedangkan kisi-kisi tersebut dibuat berdasarkan studi kepustakaan dan analisis terhadap persepsi siswa. Betolak dari landasan tersebut dikembangkan dan dicari indikator-indikatornya.

Variabel dalam penelitian ini yaitu persepsi siswa tentang manifestasi tugas-tugas perkembangan remaja Di SMA Negeri 11 Samarinda. Setelah adanya indikator tersebut, disusunlah kisi-kisi angket dan item pernyataan. Adapun kisi-kisi angket tersebut terlampir. Dalam penelitian ini, penulis menggunakan skala linkert sehingga item-item dalam angket berupa pernyataan positif-negatif.

\section{b. Pemberian Skor}

Seperti yang telah dikemukakan sebelumnya, bahwa angkrt dalam penelitian ini berdasarkan linkert yang item-itemnya dalam angket berupa pernyataan positif dan negative.

Dalam menjawab pernyataan-pernyataan tersebut, responden harus memilih salah satu dari 4 kategori jawaban yang tersedia, sesuai dengan keadaan yang siswa alami. 
Menurut Masri Singarimbun dan Sofian Efendi ( 1995 : 110 ) “ ada peneliti yang menggunakan jenjang $3(1,2,3)$, jenjang 5 ( 1 , 2, 3, 4, 5 ) dan jenjang $7(1,2,3,4,5,6,7)$. Pemberian skor untuk pernyataan positif dan negative dapat dilihat dibawah ini.

Tabel 3.3

Skor pernyataan positif dan pernyataan negative

\begin{tabular}{|c|c|c|c|c|}
\hline Pernyataan & Selalu & Sering & $\begin{array}{c}\text { Kadang- } \\
\text { kadang }\end{array}$ & Tidak pernah \\
\hline Positif & 4 & 3 & 2 & 1 \\
\hline Negatif & 1 & 2 & 3 & 4 \\
\hline
\end{tabular}

\section{c. Uji Coba Alat Ukur}

1) Uji coba angket sebagai alat ukur

Setelah angket disusun belum tentu angket tersebut dapat langsung dipergunakan untuk mengumpulkan data. Angket yang digunakan sebagai alat pengumpulan data perlu dilakukan uji validitas terlebih dahulu. Responden yang digunakan untuk uji coba sebaiknya memiliki ciri-ciri responden dari tempat dimana penelitian tersebut dilakukan. Agar penelitian distributif nilai hasil penelitian mendekati normal maka sebaiknya jumlah responden untuk uji coba paling sedikit sejumlah 30 orang. Hasil uji coba ini kemudian digunakan untuk mengetahui sejauh mana alat ukur (angket) yang telah disusun tadi memiliki validitas.

2) Uji Validitas

Validitas adalah suatu indeks yang menunjukkan alat ukur itu benar-benar mengukur apa yang diukur. Untuk mengetahui apakah angket tersebut benar-benar mengukur apa yang hendak diukur maka perlu uji korelasi skor (nilai) tiap-tiap item dengan 
skor total tersebut. Apabila angketb tersebut telah memiliki validitas, berarti semua item pertanyaan yang ada dalam angket itu mengukur konsep yang kita ukur. Alat ukur yang dapat diteima sebagai alat ukur adalah yang telah memiliki uji validitas. Uji validitas yang digunakan dalam penelitian ini adalah SPSS ( Statistical Program For Social Science ). Dalam penelitian ini untuk uji validitas diambil 20 responden dalam 1 kelas XI SMA Negeri 11 Samarinda, selanjutnya item-item yang valid akan digunakan dalam instrumen penelitian yang sebenarnya, sedangkan item-item yang tidak valid akan dihapus dan tidak dipergunakan kembali dalam instrumen penelitian yang sebenarnya karena tidak mampu mengukur apa yang sebenarnya diuku.

3) Uji Reliabilitas

Uji reliabilitas digunakan untuk mengetahui konsistensi alat ukur, apakah alat ukur yang digunakan dapat diandalkan dan tetap konsisten jika pengukuran tersebut diulang. Uji reliabilitas berguna untuk menetapkan apakah instrumen yang dalam hal ini kuisoiner dapat digunakan lebih dari satu kali, paling tidak oleh responden yang sama akan menghasilkan data yang konsisten. Dengan kata lain, reliabilitas instrumen mencirikan tingkat konsistensi. 


\section{HASIL PENELITIAN}

Data yang disajikan dalam bab ini adalah data mengenai persepsi siswa tentang manifestasi tugas-tugas perkembangan remaja siswa kelas XI SMA.Negeri 11 Samarinda Tahun Ajaran 2014/2015. Data yang diperoleh dalam penelitian ini berupa hasil skor atau nilai dari pengumpulan data melalui penyebaran angket yang kemudian diskorsing dan diberikan kepada siswa berjumlah 108 responden. Dalam pengisian jawaban skala penilaian memiliki jenjang skala $(1,2,3,4$,$) , pemberian skor pernyataan skala penilian pada variabel$ persepsi siswa tentang manifetasi tugas-tugas perkembangan remaja adalah sangat setuju $=4$, setuju $=3$, kurang setuju $=2$, tidak setuju $=1$. Sehingga dapat terlihat jumlah skor dari masing-masing responden, dimana jumlah skor dari jawaban yang telah mereka jawab dari pernyataan yang telah diberikan. Hasil penelitian yang telah dilakukan dan terkumpul dari lapangan selanjutnya diberi skor sesuai kriteria yang telah ditetapkan dan ditabulasi dalam bentuk tabel yang dapat dilihat pada pembahasan analisis data. Secara rinci data hasil penelitian ini dapat dilihat dalam bentuk tabel 4.1 berikut ini :

Tabel 4.1

Skor Angket Persepsi Siswa Tentang Manifestasi Tugas-Tugas Perkembangan Remaja

\begin{tabular}{|l|l|l|}
\hline No & Uraian & Jumlah \\
\hline 1. & Skor Tertinggi & 135 \\
\hline 2. & Skor Terendah & 71 \\
\hline 3. & Total Skor Seluruh Responden & 13090 \\
\hline
\end{tabular}

Sumber Data : Hasil Penelitian Tahun 2014

Maksud dari data hasil penelitian adalah untuk mengetahui skor tertinggi dan skor terrendah dari variabel tersebut. Dimana setelah terlihat skor tertinggi dan skor terendah maka tujuan dari skor tertinggi dan skor terendah dari skala penilian tersebut dapat dijadikan bahan untuk analisis penelitian lebih lanjut.

\section{Analisis Data}

Setelah data disajikan maka langkah selanjutnya adalah menganilisis data tersebut. Data yang dianalisis dalam penelitian ini adalah 
data tentang persepsi siswa tentang manifestasi tugas-tugas perkembangan remaja siswa kelas XI SMA.Negeri 11

\section{a. Rumus Interval}

Rumus interval digunakan untuk menentukan kategori dari studi tentang persepsi siswa tentang layanan orientasi (Sangat Baik, Baik, Cukup,dan Tidak Baik,) dengan rumus sebagai berikut:

$$
\begin{aligned}
P & =\frac{\text { skor terting } i-\text { skor terendah }}{\text { jenjang skala }} \\
& =\frac{135-71}{4} \\
& =\frac{64}{4} \\
& =16
\end{aligned}
$$

Berdasarkam hasil perhitungan interval diatas, diketahui bahwa interval persepsi siswa tentang manifestasi tugas-tugas perkembangan remaja sebanyak 16. Dengan demikian kategori persepsi siswa tentang manifestasi tugas-tugas perkembangan remaja adalah sangat baik, baik, cukup, dan tidak baik, dapat dikelompokan pada tabel dibawah ini:

\section{Tabel 4.2}

Interval Persepsi Siswa Tentang Manifetasi Tugas-Tugas

Perkembangan remaja

\begin{tabular}{|l|l|l|l|}
\hline No & Kategori & Interval & Frekuensi \\
\hline 1. & Sangat Baik & $119-135$ & 19 siswa \\
\hline 2. & Baik & $103-118$ & 47 siswa \\
\hline 3. & Cukup & $87-102$ & 36 siswa \\
\hline 4. & Tidak Baik & $71-86$ & 6 siswa \\
\hline Jumlah & & 108 siswa \\
\hline
\end{tabular}

Sumber Data : Hasil Penelitian Tahun 2015

Berdasarkan Tabel 4.2 Hal 59 terlihat bahwa persepsi siswa tentang manifestasi tugas-tugas perkembangan remaja dalam kategori Sangat Baik 19 siswa, kategori Baik 47 siswa, kategori Cukup 36 siswa, dan kategori Tidak Baik 6 siswa.

\section{b. Rumus persentase}


Rumus Persentase digunakan untuk mengetahui berapa persen jumlah masing-masing kategori persepsi siswa tentang pelaksanaan layanan orientasi dengan rumus sebagai berikut :

$$
P=\frac{f}{N} \times 100 \%
$$

Berdasarkan hasil pada tabel 4.2 tersebut, maka dilakukan perhitungan persentase sebagai berikut:

1) Sangat Baik

2) Baik

3) Cukup

4) Tidak Baik

$$
\begin{aligned}
& =P=\frac{19}{108} \times 100 \%=17,59 \% \\
& =P=\frac{47}{108} \times 100 \%=43,51 \% \\
& =P=\frac{36}{108} \times 100 \%=33,33 \% \\
& =P=\frac{6}{108} \times 100 \%=5,55 \%
\end{aligned}
$$

Berdasarkan jumlah persentase tentang manifetasi tugas-tugas perkembangan remaja selanjutnya hasil tersebut dikelompokkan kedalam masing-masing kategori sebagaimana yang termuat dalam tabel berikut ini:

\section{Tabel 4.3}

Persentase Persepsi Siswa Tentang Manifestasi Tugas-Tugas Perkembangan Remaja

\begin{tabular}{|l|l|l|l|l|}
\hline No & Kategori & Interval & Frekuensi & Persentase \\
\hline 1. & Sangat Baik & $119-135$ & 19 siswa & $17,59 \%$ \\
\hline 2. & Baik & $103-118$ & 47 siswa & $43,51 \%$ \\
\hline 3. & Cukup & $87-102$ & 36 siswa & $33,33 \%$ \\
\hline 4. & Tidak Baik & $71-86$ & 6 siswa & $5,55 \%$ \\
& & & 108 siswa & $100 \%$ \\
\hline \multicolumn{2}{|c|}{ Jumlah } & 2015 & \\
\hline
\end{tabular}

\section{Sumber Data : Hasil dari penelitian tahun 2015}

Berdasarkan tabel di atas, dapat diuraikan bahwa dari 108 siswa kelas XI SMA Negeri 11 Samarinda dari 108 siswa, terdapat 19 siswa persentase $17,59 \%$ dengan kategori sangat baik, 47 siswa persentase 43,51\% dengan kategori baik, 36 siswa persentase 33,33\% dengan kategori cukup dan 6 siswa persentase 5,55\% dengan kategori Tidak Baik. Setelah diketahui 
persentase tiap kategori kemandirian dapat dibuat diagram lingkaran sebagai berikut:

\section{Gambar 4.1}

\section{Diagram Perespsi}

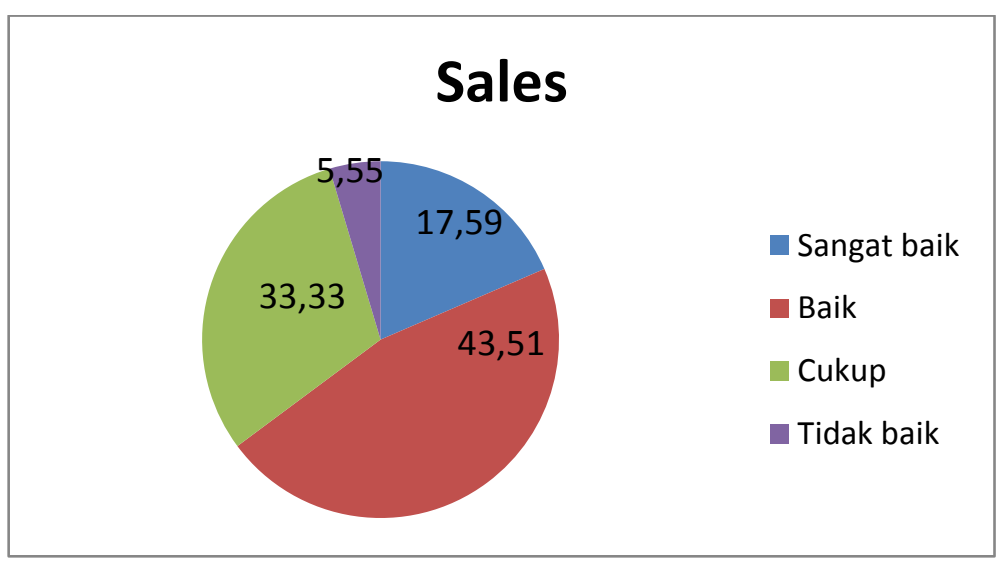

\section{A. Pembahasan Hasil Penelitian}

Berdasarkan hasil penelitian diatas dapat terlihat bahwa persepsi siswa tentang manifestasi tugas-tugas perkembangan remaja siswa kelas XI SMA Negeri 11 Samarinda dengan kategori sangat baik sebanyak 19 siswa $(17,59 \%)$, baik sebanyak 47 siswa $(43,51 \%)$, cukup sebanyak 36 siswa $(33,33 \%)$, dan tidak baik sebanyak 6 siswa $(5,55 \%)$

Hasil penelitian ini dapat menjelaskan bahwa persepsi siswa tentang manifestasi tugas-tugas perkembangan remaja merupakan suatu tugas yang harus diselesaikan setiap individu yang muncul dalam suatu periode tertentu yang harus diselesaikan setiap individu. Dan dimana penelitian ini dilakukan di sekolah yang melibatkan siswa kelas XI yang bertujuan untuk mengetahui bagaimana persepsi siswa tentang tugas-tugas perkembangan remaja. 
Dari hasil peneltian yang dilaksanakan, pada bagian terakhir penulis menyajikan bab yang menyajikan kesimpulan dari keseluruhan peneltian ini. Dan penulis juga tidak lupa memberikan saran sebagai masukan bagi penulis dan bagi pihak sekolah.

\section{KESIMPULAN}

Berdasarkan hasil analisis data dan pembahasan yang telah diuraikan pada bab 4 dapat disimpulkan bahwa Persepsi siswa tentang manifestasi tugas-tugas perkembangan remaja, menunjukan persepsi baik, adapun data yang diperoleh menunjukkan bahwa sebanyak 19 siswa dengan persentase 17,59\% mempunyai persepsi sangat baik, 47 siswa dengan persentase 43,51\% mempunyai persepsi baik, 36 siswa dengan persentase 33,33\% mempunyai persepsi cukup, dan 6 siswa dengan persentase 5,55\% mempunyai persepsi tidak baik.

\section{DAFTAR PUSTAKA}

Agoes Dariyo. 2004. Psikologi Perkembangan Remaja. Ghalia Indonesia : Bogor Selatan

Ahmad Fauzi. 1997. Psikologi Umum. Pustaka Setia : Bandung Anas Sudjono. 202. Penelitian Pendidikan, Raja Prasido : Jakarta

Azwar, Saifudin. 2002, Sikap Manusia Teori Skala dan Pengukurannya, Pustaka

Baharuddin. 2009. Pendidikan \& Psikologi Perkembangan . Ar-Ruzz Media : Jogjakarta

Bimo Walgito, 2002, Psikologi Sosial ( sauatu pengantar), andi offset, Desmita. 2012. Psikologi Perkembangan Peserta Didik. Remaja Rosdakarya : Bandung

Gunarsa D. Singgih. 2004. Psikologi Perkembangan Anaka dan Remaja. Gunung: Mulia : Jakarta

Hartinah Sitti. 2011. Pengembangan Peserta Didik. Refika Aditama : Bandung http://midcare.Blogspot.com/2012/01/01/tujuan-perkembanganremaja.html $m=1$. Diakses pada selasa 10 februari 2015. Pukul 11.35. http://rudisiswoyo89.blogspot.com/2013/11/karakteristik-perkembanganremaja.html? $m=1$. Diakses pada hari selasa 10 februari 
Kartini Kartono. 1990. Psikologi Umum. Penerbit Mandar, Maju : Bandung Masri singarimbun \& Sofian effendi. 1989. Metode Penelitian Survai. Pustaka LP3ES

Moleong, Lexy. 2004. Metodologi Penelitian Kualitatif. PT.Remaja Rosdakarya : Bandung

Sugiono. 2006. Metode Penelitian Pendidikan. Alfabeta : Bandung

Sugiyono. 2010. Metode Penelitian Kuantitatif dan Kualitatif dan R\&D. Alfabeta Bandung

Suharsimi Arikunto. 1998. Prosedur Penelitian Suatu Pendekatan dalam Praktek. Rieneka Cipta: Jakarta

Suharsimi Arikunto. 2006. Prosedur Penelitian Suatu Pendekatan Praktek Edisi Revisi VI. Rieneka Cipta : Jakarta.

Sumanto. 2014. Psikologi Perkembangan Fungsi dan Teori. CAPS ( Center of Academic Pubhlishing Service ) : Jakarta

Sunarto dan Agung Hartono. 2008. Perkembangan Peserta Didik. Rineka Cipta : Jakarta

Sunaryo. 2004. Psikologi Untuk Keperawatan. EGC : Jakarta

Sutrisno Hadi. 2004. Metodologi Research Yogjakarta 